The Mathematical Imagination 



\title{
The Mathematical Imagination
}

\section{On the Origins and Promise of Critical Theory}

\author{
Matthew Handelman
}

F ORDHAM UN IVERSITY PRESS

NEW YORK 2 O I 9 
This book is freely available in an open access edition thanks to TOME (Toward an Open Monograph Ecosystem)—a collaboration of the Association of American Universities, the Association of University Presses, and the Association of Research Librariesand the generous support of Michigan State University. Learn more at the TOME website, available at: openmonographs.org.

This work is licensed under a Creative Commons AttributionNonCommercial-NoDerivatives 4.o International License.

\section{(c) (1) ( $) \Theta$}

Through the generous funding of Michigan State University, this publication is available on an open access basis from the publisher's website.

Fordham University Press gratefully acknowledges financial assistance and support provided for the publication of this book by Michigan State University.

\section{Copyright @ 2019 Fordham University Press}

All rights reserved. No part of this publication may be reproduced, stored in a retrieval system, or transmitted in any form or by any means-electronic, mechanical, photocopy, recording, or any other-except for brief quotations in printed reviews, without the prior permission of the publisher.

Fordham University Press has no responsibility for the persistence or accuracy of URLs for external or third-party Internet websites referred to in this publication and does not guarantee that any content on such websites is, or will remain, accurate or appropriate.

Fordham University Press also publishes its books in a variety of electronic formats. Some content that appears in print may not be available in electronic books.

Visit us online at www.fordhampress.com.

Library of Congress Cataloging-in-Publication Data available online at https://catalog.loc.gov.

Printed in the United States of America

$\begin{array}{llllllll}2 \text { I } & 20 & \text { I9 } & 5 & 4 & 3 & 2 & \text { I }\end{array}$

First edition 